\title{
Evaluation of alternative macroinvertebrate sampling techniques for use in a new tropical freshwater bioassessment scheme
}

\author{
Uma avaliação de técnicas alternativas de amostragem de macroinvertebrados \\ para uso na bioavaliaçáo de sistemas aquáticos tropicais
}

\author{
Isabel Eleanor Moore ${ }^{1}$ and Kevin Joseph Murphy \\ ${ }^{1}$ University of Glasgow, University Avenue, Glasgow, G12 8QQ, Scotland \\ e-mail: isabelmoore89@gmail.com; mearnskevin@googlemail.com
}

\begin{abstract}
Aim: The study aimed to determine the effectiveness of benthic macroinvertebrate dredge net sampling procedures as an alternative method to kick net sampling in tropical freshwater systems, specifically as an evaluation of sampling methods used in the Zambian Invertebrate Scoring System (ZISS) river bioassessment scheme. Tropical freshwater ecosystems are sometimes dangerous or inaccessible to sampling teams using traditional kick-sampling methods, so identifying an alternative procedure that produces similar results is necessary in order to collect data from a wide variety of habitats. Methods: Both kick and dredge nets were used to collect macroinvertebrate samples at 16 riverine sites in Zambia, ranging from backwaters and floodplain lagoons to fast flowing streams and rivers. The data were used to calculate ZISS, diversity (S: number of taxa present), and Average Score Per Taxon (ASPT) scores per site, using the two sampling methods to compare their sampling effectiveness. Environmental parameters, namely $\mathrm{pH}$, conductivity, underwater photosynthetically active radiation (PAR), temperature, alkalinity, flow, and altitude, were also recorded and used in statistical analysis. Invertebrate communities present at the sample sites were determined using multivariate procedures. Results: Analysis of the invertebrate community and environmental data suggested that the testing exercise was undertaken in four distinct macroinvertebrate community types, supporting at least two quite different macroinvertebrate assemblages, and showing significant differences in habitat conditions. Significant correlations were found for all three bioassessment score variables between results acquired using the two methods, with dredge-sampling normally producing lower scores than did the kick net procedures. Linear regression models were produced in order to correct each biological variable score collected by a dredge net to a score similar to that of one collected by kick net sampling. Conclusions: The use of a dredge net in macroinvertebrate bioassessment schemes is an effective, alternative method in certain environments when site conditions prohibit the use of the preferred kick net sampling method. The results of this study can be used to aid in the development of other tropical freshwater bioassessment schemes around the world, including Brazil.
\end{abstract}

Keywords: limnology; Zambia; ZISS: Zambian Invertebrate Scoring System; dredge net; kick net; benthic invertebrates.

Resumo: Objetivo: Este estudo pretendeu determinar a eficácia dos procedimentos de amostragem de macroinvertebrados bentônicos em sistemas aquáticos tropicais, através de rede de dragagem ("dredge net") em alternativa ao método de rede de pontapé ("kick net"), particularmente na avaliação dos métodos de amostragem utilizados no Sistema de Classificação de Invertebrados de Zâmbia (ZISS). Os ecossistemas tropicais de água doce são algumas vezes inacessíveis ou perigosos de serem amostrados com o método tradicional de rede de pontapé, assim é necessário encontrar um procedimento alternativo que permita a obtenção de resultados semelhantes para a coleta de dados em uma grande variedade de habitats. Métodos: Ambos os métodos de amostragem (rede de dragagem e rede de pontapé) foram usados para coletar amostras de macroinvertebrados em 16 locais em Zâmbia, abrangendo desde remansos e lagoas de inundação, até riachos e rios de grande velocidade de corrente. Os dados foram usados para o cálculo de ZISS, diversidade (S: número de táxons) e escores por local (Average Score Per Taxon: ASPT), usando os dois métodos de amostragem para comparar a sua eficiência de amostragem. As variáveis $\mathrm{pH}$, condutividade, radiação fotossinteticamente ativa (RFA), temperatura, alcalinidade, velocidade de corrente e altitude também foram obtidas e usadas nas análises estatísticas. 
As comunidades de invertebrados presentes nos locais de coleta foram determinadas através de procedimentos multivariados. Resultados: A análise da comunidade de invertebrados e dos dados ambientais sugerem que o teste foi realizado em quatro tipos distintos de comunidades de invertebrados, com pelo menos dois agrupamentos muito diferentes entre si e mostrando diferenças significativas nas condiçóes dos habitats. Correlaçóes significativas foram encontradas para todos os três escores das variáveis de bioavaliação entre os resultados obtidos usando os dois métodos, com a rede de dragagem produzindo normalmente menores escores do que aqueles com o procedimento com a rede de pontapé. Modelos de regressáo linear foram produzidos para corrigir o escore de cada variável biológica coletada com a rede de dragagem com o escore similar daquele coletado com a rede de pontapé. Conclusóes: $\mathrm{O}$ uso da rede de dragagem na bioavaliaçáo com macroinvertebrados é um método alternativo efetivo em certos ambientes nos quais as condiçóes proíbem o uso do método preferencial de rede de pontapé. Os resultados deste estudo podem ser usados como auxílio no desenvolvimento da bioavaliação em outros ambientes de água doce tropicais do mundo, incluindo o Brasil.

Palavras-chave: limnologia; Zâmbia; ZISS: Sistema de Classificação de Invertebrados da Zâmbia; rede de dragagem; rede de pontapé; invertebrados bentônicos.

\section{Introduction}

The use of bioassessment methods to determine water quality in freshwater systems has become common practice in many countries around the world, including the United States, South Africa, Australia, and all countries of the European Union (e.g. Wright et al., 1998; Smith et al., 1999; Barbour et al., 1999; Swedish Environmental Protection Agency, 2000; Dickens \& Graham, 2002; Murphy et al., 2002; Ollis et al., 2006; Dallas et al., 2010; Friberg et al., 2010; Turley et al., 2014). These simple biologically-based assessment protocols are often less expensive and produce faster results than traditional physico-chemical testing, and use the presence of various different aquatic indicator taxa to give a quantitative measure of the health of the freshwater ecosystem (Lowe et al., 2012a; Turley et al., 2014). Although there are as yet no internationally-agreed sampling procedures for freshwater bioassessment, trends can be seen between aquatic communities that demonstrate enough similarities to permit basic comparisons to be drawn between ecoregions (Abell et al., 2008), and sampling protocols for new bioassessment schemes to be adapted from previous ones (e.g. Murphy et al., 2002; Lowe et al., 2012a; Buss et al., 2015).

Macroinvertebrates are a commonly used indicator group for this purpose, as are fish, benthic diatoms, and macrophyte communities (e.g. Barbour et al., 1999), because the presence or absence of various taxa (usually at family level) in a freshwater ecosystem is strongly correlated with environmental parameters, such as temperature, toxic pollutants, and suspended sediment (Ogbeibu
\& Oribhabor, 2002; Durance \& Ormerod, 2009; Clapcott et al., 2012; Xu et al., 2014).

A number of countries in tropical Africa, Asia and South America, including Brazil, have been developing macroinvertebrate-based bioassessment methods for their own aquatic ecosystems (e.g. Palmer et al., 1996; Junqueira \& Campos, 1998; Junqueira et al., 2000; Palmer \& Taylor, 2004; Silveira et al., 2005; Buss \& Borges, 2008; Monteiro et al., 2008; Roque et al., 2008; Dallas, 2009; Hartmann et al., 2010; Lowe et al., 2012a; Melo et al., 2015). The Zambian Invertebrate Scoring System (ZISS) is one such example. This scheme has been recently developed to help determine the quality of tropical freshwater systems by sampling macroinvertebrate communities in Zambian rivers (Lowe et al., 2012a). Because there had been very few preceding studies of the macroinvertebrate populations and water quality of Zambia's rivers, this scheme effectively commenced the process of biomonitoring the health of freshwater systems in this tropical country (Lowe et al., 2012a).

The ZISS scheme uses a kick net sampling procedure as its standard approach for sampling benthic macroinvertebrate communities (Lowe et al., 2012a, b). It is not, however, always possible to use this method in Zambian rivers, particularly because of the potential threat posed by dangerous aquatic wildlife (e.g. hippopotamus and crocodiles), which may make entering a water body on foot too dangerous. Because of this problem, it is important to have an alternative method that produces comparable results to the kick net approach, in order to obtain appropriate bioassessment data from sites in Zambia, and in 
other tropical freshwater systems with similar safety issues.

The purpose of this study was to determine if a dredge net, which can safely be used to collect samples from the bank of a water body, or from a boat, can produce similar results to the data on Zambian benthic invertebrate communities that are obtained by kick net sampling. Any quantitative and significant relationship found between the data collected by the kick net and the dredge net approaches could be used to correct the results from dredge net sampling data to results similar to those collected by kick net sampling.

\section{Material and Methods}

\subsection{Study area}

Zambia is a landlocked, southern African country centred at $15^{\circ} 00^{\prime} \mathrm{S}$ and $30^{\circ} 00^{\prime} \mathrm{E}$. Sampling for this study was undertaken in the northern half of the country, located in the Kasanka National Park, and Bangweulu Wetlands (located in freshwater ecoregion Bangweulu-Mweru: Abell et al., 2008; WWF, 2013); and in the South
Luangwa National Park (freshwater ecoregion: Middle Zambezi-Luangwa), and included riverine floodplain aquatic systems such as backwaters and lagoons, as well as small to medium-sized river channels. In total, 25 sites (Figure 1, Table 1) were sampled in July 2013, during the southern African dry season, resulting in low water levels and no rainfall being encountered during the sampling period. The geo-coordinates and altitude of each site were recorded using a handheld Garmin Etrex GPS unit.

\subsection{Field sampling}

Sample collection by kick net sampling (mesh size $=1 \mathrm{~mm}$ ) followed the protocol outlined by the Zambian Invertebrate Scoring System (Lowe et al., 2012b), with minor adjustments to the time-period spent sampling due to local conditions at individual sites. Up to three biotopes (as present at each site, namely sand gravel, mud; rock; aquatic vegetation) were sampled and the results combined to characterize the site. At all sites a dredge net (mesh size $=1 \mathrm{~mm})$, attached to a $5 \mathrm{~m}$ cord, was also used to sample invertebrates from each biotope.

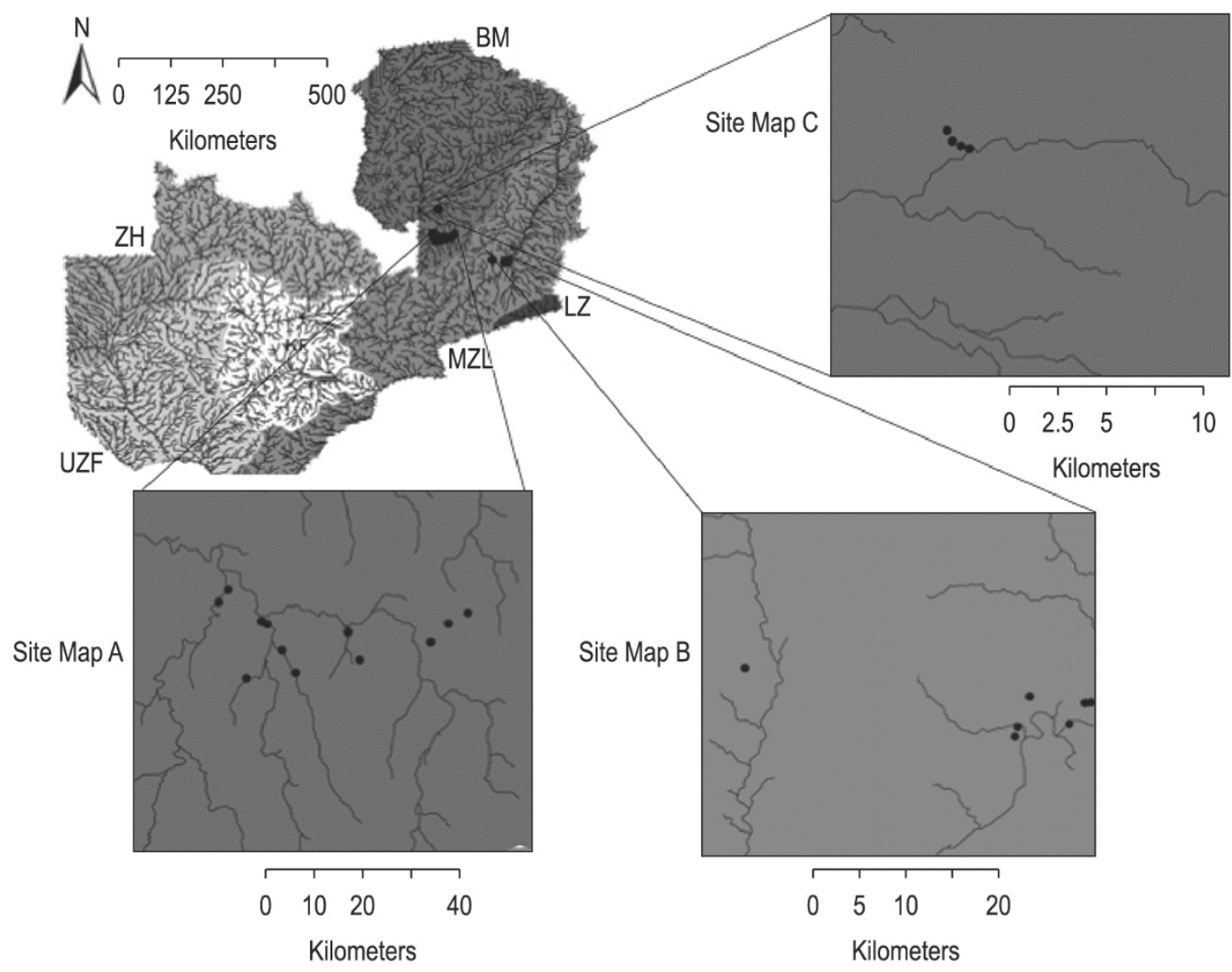

Figure 1. Map of Zambia with sampling sites shown in greater detail in additional sub site maps. Site Map A shows sites sampled in Kasanka National Park. Site Map B shows sites sampled in South Luangwa National Park. Site Map C shows sites sampled in the Bangweulu Wetlands. 
Table 1. Coordinates for sites sampled in Zambia.

\begin{tabular}{|c|c|c|c|}
\hline $\begin{array}{c}\text { Site } \\
\text { Number }\end{array}$ & Site Name & Lat (S) & Long (E) \\
\hline 1 & Njelele & 12.60864 & 30.39989 \\
\hline 2 & Mulaushi & 12.55637 & 30.37608 \\
\hline 3 & Fibwe & 12.59168 & 30.25193 \\
\hline 4 & Mulembo & 12.53797 & 30.56644 \\
\hline 5 & Pontoon & 12.57262 & 30.53353 \\
\hline 6 & Kabombe & 12.64557 & 30.18482 \\
\hline 7 & Luwombwa & 12.50248 & 30.13113 \\
\hline 8 & $\begin{array}{l}\text { Luwombwa } \\
\text { Backwater }\end{array}$ & 12.47837 & 30.14912 \\
\hline 9 & Musola & 12.63367 & 30.27768 \\
\hline 10 & Shoebill A & 11.95111 & 30.23965 \\
\hline 11 & Shoebill B & 11.95321 & 30.24393 \\
\hline 12 & Shoebill C & 11.95445 & 30.24785 \\
\hline 13 & Shoebill D & 11.95047 & 30.23976 \\
\hline 14 & Shoebill E & 11.94584 & 30.2372 \\
\hline 15 & Waka Waka & 12.51621 & 30.60274 \\
\hline 16 & Kasanka River & 12.5381 & 30.21224 \\
\hline 17 & $\begin{array}{l}\text { Kasanka } \\
\text { Backwater }\end{array}$ & 12.54324 & 30.22299 \\
\hline 18 & Wakumba & 13.10507 & 31.72647 \\
\hline 19 & Wakumba II & 13.11465 & 31.72385 \\
\hline 20 & No Name (20) & 13.07476 & 31.73746 \\
\hline 21 & Luwangwamafwa & 13.06166 & 31.81711 \\
\hline 22 & Chipela Lagoon & 13.052 & 31.45268 \\
\hline 23 & $\begin{array}{c}\text { Luwangwa } \\
\text { River (Main) }\end{array}$ & 13.10128 & 31.77786 \\
\hline 24 & $\begin{array}{l}\text { Mushroom } \\
\text { Lagoon }\end{array}$ & 13.08023 & 31.79352 \\
\hline 25 & No Name (25) & 13.07927 & 31.79935 \\
\hline
\end{tabular}

All collected macroinvertebrates were identified (usually to family level: see Table 3) on site, using a hand lens and a photographic identification manual developed specifically for ZISS, which lists all commonly found invertebrate families in Zambian rivers (Lowe, 2012). Subsequent confirmation of identifications was made using a portable microscope. Macroinvertebrate samples were stored in $70 \%$ ethanol to preserve them for future study.

The ZISS index, diversity (S: number of taxa present), and Average Score Per Taxon (ASPT) scores were calculated for each site, and individual scores were also calculated for each sampling method used at the sites.

Environmental parameters measured at the sampling sites were $\mathrm{pH}$; conductivity; underwater photosynthetically active radiation (PAR; at two points in the water column: just below surface and at standard depth of $0.22 \mathrm{~m}$ unless the water was too shallow, in which case a smaller separation depth was used for the second reading), with PAR data subsequently used to calculate underwater light attenuation coefficient $\left(\mathrm{k} \mathrm{m}^{-1}\right)$; temperature; visually-assessed disturbance class (on a semi-quantitative scale of $1=$ no disturbance due to trampling by animals, to $4=$ substantial disturbance: major trampling damage); and visually-assessed flow class (class $1=$ static; $2=$ slow flow: "pool"; 3 = moderate flow: "glide"; 4 = fast

Table 2. Environmental and biological parameters: range of data for all 25 sites, and mean \pm standard error (SE) for each of four TWINSPAN sample groups compared by ANOVA.

\begin{tabular}{|c|c|c|c|c|c|c|}
\hline & \multicolumn{6}{|c|}{ TWINSPAN Sample Groups } \\
\hline & & $\mathrm{I}$ & II & III & IV & $\mathbf{P}_{\text {ANOVA }}$ \\
\hline Variable & Range & Mean \pm SE & Mean \pm SE & Mean \pm SE & Mean \pm SE & \\
\hline $\mathrm{pH}$ & $6.00-9.36$ & $7.67 \pm 0.14^{\mathrm{a}}$ & $7.25 \pm 0.12^{\mathrm{a}}$ & $7.89 \pm 0.27^{a}$ & $6.55 \pm 0.27^{b}$ & $<0.005$ \\
\hline $\begin{array}{l}\text { Temperature } \\
\left({ }^{\circ} \mathrm{C}\right)\end{array}$ & $12.00-29.90$ & $20.5 \pm 1.79$ & $20.66 \pm 2.22$ & $19.7 \pm 8.68$ & $22.05 \pm 1.87$ & $>0.05 \mathrm{NS}$ \\
\hline Flow & $1.00-4.00$ & $1.50 \pm 0.50^{\mathrm{a}}$ & $1.29 \pm 0.18^{\mathrm{a}}$ & $3.00 \pm 0.31^{b}$ & $1.50 \pm 0.29^{a}$ & $<0.005$ \\
\hline Disturbance & $1.00-4.00$ & $2.00 \pm 0.37^{\mathrm{a}}$ & $2.14 \pm 0.26^{\mathrm{a}}$ & $1.14 \pm 0.14^{b}$ & $1.50 \pm 0.29^{\mathrm{a}}$ & $<0.05$ \\
\hline $\begin{array}{l}\text { Conductivity } \\
\left(\mu \mathrm{S} \mathrm{cm}{ }^{-1}\right)\end{array}$ & $6.00-625.00$ & $217.30 \pm 99.43$ & $84.00 \pm 23.62$ & $53.00 \pm 17.69$ & $30.50 \pm 12.20$ & $>0.05 \mathrm{NS}$ \\
\hline$k\left(m^{-1}\right)$ & $0.70-26.86$ & $12.16 \pm 5.00$ & $11.45 \pm 4.58$ & $4.62 \pm 2.41$ & $11.32 \pm 4.95$ & $>0.05 \mathrm{NS}$ \\
\hline $\begin{array}{l}\text { Alkalinity } \\
\text { (microEq L-1) }\end{array}$ & $78.22-4386.29$ & $1845.00 \pm 676.60$ & $1055.00 \pm 329.55$ & $844.00 \pm 286.47$ & $552.00 \pm 262.00$ & $>0.05 \mathrm{NS}$ \\
\hline Altitude (m) & $511.00-1273.00$ & $858.00 \pm 154.43$ & $886.90 \pm 130.99$ & $1085.10 \pm 95.77$ & $1168.00 \pm 8.60$ & $>0.05 \mathrm{NS}$ \\
\hline Kick $_{s}$ & $3.000-16.00$ & $9.00 \pm 1.29$ & $9.00 \pm 0.82$ & $10.57 \pm 1.48$ & $5.25 \pm 0.48$ & $>0.05 \mathrm{NS}$ \\
\hline Dredge $_{\mathrm{s}}$ & $0.00-12.00$ & $6.33 \pm 1.41$ & $7.29 \pm 1.30$ & $6.28 \pm 1.60$ & $3.75 \pm 0.85$ & $>0.05 \mathrm{NS}$ \\
\hline Kick $_{\text {ASPT }}$ & $3.00-6.82$ & $4.24 \pm 0.29$ & $4.58 \pm 0.43$ & $4.83 \pm 0.39$ & $3.56 \pm 0.26$ & $>0.05 \mathrm{NS}$ \\
\hline Dredge $_{\text {ASPT }}$ & $0.00-5.25$ & $3.89 \pm 0.49$ & $4.04 \pm 0.19$ & $3.68 \pm 0.64$ & $3.83 \pm 0.15$ & $>0.05 \mathrm{NS}$ \\
\hline Kick $_{\text {zlss }}$ & $10.00-79.00$ & $38.83 \pm 6.85^{a}$ & $40.71 \pm 3.95^{\mathrm{a}}$ & $53.00 \pm 8.66^{a}$ & $18.75 \pm 2.46^{b}$ & $<0.05$ \\
\hline Dredge $_{\text {ziss }}$ & $0.00-52.00$ & $26.50 \pm 6.34$ & $30.57 \pm 6.19$ & $27.57 \pm 7.30$ & $14.50 \pm 3.71$ & $>0.05 \mathrm{NS}$ \\
\hline
\end{tabular}

For variables with significant ANOVA outcomes only $(\mathrm{P}<0.05)$ mean values with a superscript letter in common do not significantly differ between sample groups (Tukey's mean separation test). No statistical test was applied to geo-coordinates data. 
flow: "riffle" or white water showing). Field meters used were a Handylab $\mathrm{pH} /$ temperature LF12 meter, HI98311 conductivity meter, and a SKYE SKP210 underwater PAR sensor. A water sample was taken at each site for subsequent alkalinity analysis (Neal, 2001).

\subsection{Data analysis}

Ryan-Joiner testing was used to determine the normality of the response data for each variable subject to statistical testing, and a natural log transformation was used to normalize datasets if needed. In order to determine the range of benthic macroinvertebrate communities present at the test sites, and their relationship with ambient environmental conditions, the macroinvertebrate and environmental data were analyzed using the multivariate ordination method Canonical Correspondence Analysis, (CCA; Version 4.5 CANOCO for Windows), to analyze both the samples versus taxa datasets and the samples versus environmental variables dataset (ter Braak \& Smilaŭer, 1998). The significance of ordination outcomes was determined by Monte Carlo testing. In addition, Two-Way Indicator Species Analysis (TWINSPAN) was used to classify taxa datasets into internally similar groups (Hill, 1979). Comparisons were made between mean values of 10 variables ( $\mathrm{pH}$, conductivity, flow class, turbidity $\left(\mathrm{k} \mathrm{m}^{-1}\right)$, disturbance class, alkalinity, altitude, diversity (S), ZISS, and ASPT) for sample groups produced by TWINSPAN using one-way analysis of variance (ANOVA: with Tukey's multiple-comparison test for significant outcomes), using Minitab, version 15.1.30.0. Data presented (see Table 2) were back-transformed (for variables where significance testing had been undertaken using log values) for ease of comparison.

\section{Results}

In total, 42 different benthic macroinvertebrate taxa from 13 groups/orders were collected at the sample sites (Table 3). TWINSPAN classification identified four main sample groups (I-IV) and two main taxa assemblages (A and B). Assemblage A ( $n=24$ taxa) comprised taxa such as Corixidae and Culicidae which both have high abundances in sample groups I and II, but were almost completely absent from sample groups III and IV. Assemblage $\mathrm{B}(n=20$ taxa) was made up of taxa such as Atyidae and Leptoceridae, which were commonly found in sample groups III and IV, but are absent from groups I and II. These differing assemblages suggest that there was a substantial difference between the sites where Assemblage A taxa were more commonly found, and the sites where Assemblage B taxa were predominant.

The four sample groups differed significantly in terms of a number of the biological and

Table 3. Macroinvertebrate families and orders recorded from sample sites. Following ZISS protocol, sampled taxa are identified mostly to family level (Lowe et al., 2012a). However, there are some exceptions, including Annelida, Oligochaeta, and Turbellaria which are only required to be identified to subphylum or class and are listed below in bold.

\begin{tabular}{|c|c|}
\hline Group/Order & Family \\
\hline \multicolumn{2}{|l|}{ Annelida } \\
\hline \multirow[t]{5}{*}{ Coleoptera } & Noteridae/Dytiscidae \\
\hline & Limnichidae \\
\hline & Hydrophilidae \\
\hline & Gyrinidae \\
\hline & Hapliplidae \\
\hline Decapoda & Atyidae \\
\hline \multirow[t]{4}{*}{ Diptera } & Chironomidae \\
\hline & Culicidae \\
\hline & Simuliidae \\
\hline & Dixidae \\
\hline \multirow[t]{4}{*}{ Ephemeroptera } & Baetidae \\
\hline & Prosopistomatidae \\
\hline & Tricorythidae \\
\hline & Caenidae \\
\hline \multirow[t]{8}{*}{ Gastropoda } & Lymnaeidae \\
\hline & Planorbinae \\
\hline & Bithyniidae \\
\hline & Ancylidae \\
\hline & Ampularidae \\
\hline & Bulininae \\
\hline & Hydrobiidae \\
\hline & Thiaridae \\
\hline \multirow[t]{6}{*}{ Hemiptera } & Gerridae \\
\hline & Nepidae \\
\hline & Naucoridae \\
\hline & Veliidae \\
\hline & Corixidae \\
\hline & Notonectidae \\
\hline \multicolumn{2}{|l|}{ Hirudinae } \\
\hline Lepidoptera & Crambidae \\
\hline \multirow[t]{4}{*}{ Odonata } & Libellulidae \\
\hline & Coenagrionidae \\
\hline & Calopterygidae \\
\hline & Aeshnidae \\
\hline \multicolumn{2}{|l|}{ Oligochaeta } \\
\hline Pelecypoda & Sphaeriidae \\
\hline Plecoptera & Perlidae \\
\hline \multicolumn{2}{|l|}{ Potamonautidae } \\
\hline \multirow[t]{3}{*}{ Trichoptera } & Leptoceridae \\
\hline & Hydropsychidae \\
\hline & Polycentropodidae \\
\hline Turbellaria & \\
\hline
\end{tabular}


environmental variables measured (Table 2). Indicator taxa distinguishing them are listed below (note that under the ZISS system, the presence of $>1$ species within certain families differentiates them, and provides differing ZISS scores; e.g. Baetidae: 1 species = ZISS score 4; 2 species $=$ ZISS score 6; $>2$ species $=$ ZISS score 12 (Lowe et al., 2012c)). Group I was indicated by Gyrinidae, Culicidae, Gerridae, and Ampularidae; Group II: Baetidae (1 species) and Oligochaeta; Group III:- Coenagrionidae, Baetidae (2 species), Libellulidae, Baetidae (1 species), Atyidae, and Leptoceridae; and Group IV: Hydrophilidae.

Significant differences in environmental and biological variables between sample groups, (detailed in Table 2) can be summarised as follows: Groups I and II: high disturbance and conductivity, low altitude and flow, fewer pollution-sensitive taxa (such as Oligochaeta and Corixidae); Groups III and IV: low disturbance and conductivity, high altitude and flow, presence of more sensitive taxa (such as Atyidae and Coenagrionidae).

The ordination analysis (Figure 2) indicated the importance of flow, disturbance, altitude, and conductivity as major predictors of macroinvertebrate community. Less important environmental drivers include water clarity, $\mathrm{pH}$, and alkalinity. When TWINSPAN groups were overlaid onto the ordination site-plot, the different site-groups were shown to be associated with varying environmental parameters

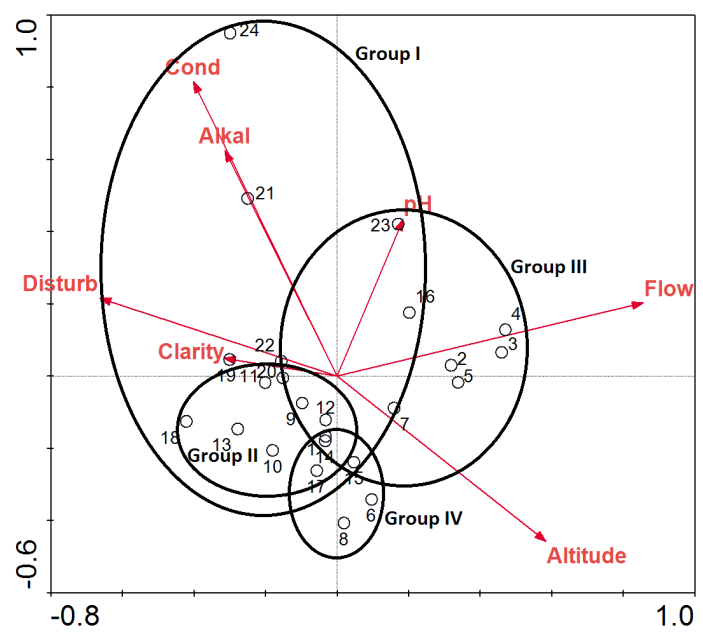

Figure 2. CCA site ordination plot with TWINSPAN sample-groups overlain, showing relation between environmental variables and 4 site-groups (I: characterised by abundant Gerridae, Gyrinidae, Culicoidae, and Ampularidae; II: Baetidae (single species), Oligochaetae; III: Coenagrionidae, Libellulidae, Baetidae ( $>1$ species), Atyidae and Leptoceridae; IV: abundant Hydrophilidae). and influenced slightly by their geographical location. Sites sampled in South Luangwa and the Bangweulu Wetlands were found primarily in Groups I and II, while Groups III and IV were mostly comprised of sites located in Kasanka National Park.

In order to assess the usefulness of the dredge-sampling approach, compared with the standard kick-sample protocol, across the range of invertebrate communities and environmental conditions present at the survey sites, a series of comparisons was made, as detailed below.

The highest ZISS score, at any site, recorded by kick-sampling was 79 (indicating very good river ecosystem health), whilst the lowest (10) indicated poor water conditions at that particular site. The comparison of the three metrics ZISS, diversity (S) and ASPT scores, using data collected by each sampling method, showed a difference between the values produced by kick net sampling and the values produced by dredge net sampling, with dredge-sampling usually underestimating the values produced by kick-sampling. Whilst all kick net samples yielded invertebrate specimens, some dredge net samples failed to collect invertebrates at all: for example when bedrock was the substratum, resulting in scores of zero for ZISS, S, and ASPT. A significant statistical correlation between dredge score and maximum score was found between the calculated values of each quantitative biological variable, which allowed linear regression models to be created that could be used to correct scores derived from the less-efficient dredge-sampling method.

A significant positive correlation was found between the maximum ZISS score recorded at each site and the ZISS score recorded from samples collected by a dredge net $(r=0.532, p=0.034$, $\left.r^{2}(\operatorname{adj})=23.3 \%\right)$. A linear regression analysis produced the equation:

Kick $_{\text {ZISS }}=22.6+0.633$ Dredge $_{\text {ZISS }}$

which can be used to correct ZISS scores collected by dredge-sampling to a score similar to that of one collected by kick net sampling.

There was a significant positive correlation between macroinvertebrate diversity $(S)$ collected by dredge net and kick net sampling $(r=0.547$, $p=0.028, r^{2}($ adj $\left.)=24.9 \%\right)$. A linear regression analysis produced the equation:

Kick $_{S}=4.71+0.608$ Dredge $_{S}$

which can be used to correct diversity scores collected by dredge-sampling to a score similar to that of one collected by kick net sampling. 
There was a significant negative correlation between the ASPT scores collected by dredge-sampling and kick net sampling $(r=-0.525$, $\left.p=0.037, r^{2}(a d j)=22.4 \%\right)$. A linear regression analysis of ASPT scores collected by kick net and by dredge net produced the equation:

Kick $_{\text {ASPT }}=-5.98-0.419$ Dredge $_{\text {ASPT }}$

which can be used to correct scores collected by dredge net sampling to the standard kick-net based score utilised in ZISS protocol for assessing river water quality.

\section{Discussion}

Since kick net sampling is considered to be a highly-effective method of collecting an accurate representation of benthic macroinvertebrate communities, it continues to be the standard choice of sampling protocol for use in river bioassessment procedures utilising benthic invertebrates (Buss \& Borges, 2008; Brua et al., 2011; Buss et al., 2015). Dredge-sampling is less efficient because it produces less disturbance of the invertebrate habitat during the sampling operation than does kick-sampling, and hence tends to dislodge and collect a smaller proportion of the taxa present. However, in conditions where environmental conditions (such as the presence of dangerous wildlife, inaccessibility due to water depth or fast flow) prevent the use of procedures which require sampling personnel to enter the water, an alternative method of sampling must be identified, which produces data that can be converted back to results that would be obtained by standard kick-sampling. So long as the two methods produce comparable values for benthic metrics and community composition, then samples collected by either method should be able to be combined for bioassessment purposes (Brua et al., 2011). Here we show that this is possible for bank- or boat-based dredge-sampling, by utilising simple linear regression models (Equations 1-3) to correct and standardise the results obtained by the dredge-sampling procedure so that the data can be used in the ZISS assessment protocol. This allows a less efficient (but safer) sampling methodology to be used where a more efficient procedure might not be an option.

This study provides an initial indication of the potential value of dredge-sampling for bioassessment using benthic macroinvertebrate populations in tropical rivers and associated riverine floodplain water bodies, and shows that the results obtained can be relied upon, after correction for the known inefficiency of the technique, using the models presented here (Equations 1-3) to collect samples that reasonably and accurately represent the macroinvertebrate communities present at a selected site. At sites where both methods were used, the dredge usually collected a lower diversity of taxa and gave a lower total ZISS score, but by using linear regression equations, the ZISS, diversity, and ASPT scores collected by dredge-sampling can be corrected to estimate results similar to those that would have been collected by a kick net. However, because the correlations between the variable scores of both methods only explained a moderate proportion of the variability, each with an estimated $r$-value of 0.500-0.600, it is clear that more data needs to be collected, across a wider range of appropriate habitats, to permit the development of more precise correction factors for the dredge method. Future dredge protocol development is also needed in order to ensure that the sampling effort of using a dredge-sampler is the same as the effort of using a kick net. The dredge protocols used in this study, however, did seem to produce relatively similar results to that of the kick net at each site, so they can be considered a good base to build upon.

\section{Conclusions}

This study indicated that results found by two different macroinvertebrate sampling methods are statistically significantly-related, across a range of sites located in different ecoregions in Africa, and supporting differing habitat conditions and invertebrate communities. This knowledge is beneficial in the development of biomonitoring systems that are required to sample a large range of different aquatic habitats in tropical rivers with varying restrictions on sampling methods. Improved availability of alternative approaches for sampling in river bioassessment schemes can contribute to improved understanding of the health of tropical aquatic systems, and the challenges that are faced in maintaining such water resources in good quality.

\section{Acknowledgements}

An abbreviated version of this paper was presented as a poster and abstract at the 14th Brazilian Limnological Congress, Bonito, MS, in September 2013. We thank Dr. Mike Kennedy (University of Aberdeen, Scotland) and Dra. Celeste Franceschini (CECOAL, Argentina) for their support and companionship during the fieldwork for this study. Permission to undertake fieldwork in Zambian conservation areas was granted by the 
Zambian Wildlife Authority (ZAWA). We thank the ZAWA and Kasanka Trust game scouts who accompanied and protected the team during our field sampling trips, as well as numerous members of staff of the Kasanka Conservation Centre, Shoebill Camp, and Flatdogs Camp for their help. We also thank Sara Varandas Martins for the Portuguese translation and Dr. Steven Lowe for his technical support. This study was funded in part by a grant to Dr. Kevin Murphy from the Carnegie Trust for the Universities of Scotland.

\section{References}

ABELL, R., THIEME, M.L., REVENGA, C., BRYER, M., KOTTELAT, M., BOGUTSKAYA, N., COAD, B., MANDRAK, N., BALDERAS, S.C., BUSSING, W., STIASSNY, M.L.J., SKELTON, P., ALLEN, G.R., UNMACK, P., NASEKA, A., NG, R., SINDORF, N., ROBERTSON, J., ARMIJO, E., HIGGINS, J.V., HEIBEL, T.J., WIKRAMANAYAKE, E., OLSON, D., LÓPEZ, H.L., REIS, R.E., LUNDBERG, J.G., SABAJ PÉREZ, M.H. and PETRY, P. Freshwater ecoregions of the world: a new map of biogeographic units for freshwater biodiversity conservation. Bioscience, 2008, 58(5), 403-414. http://dx.doi.org/10.1641/ B580507.

BARBOUR, M.T., GERRITSEN, J., SNYDER, B.D. and STRIBLING, J.B. Rapid bioassessment protocols for use in streams and wadeable rivers: periphyton, benthic macroinvertebrates and fish. 2nd ed. Washington: United States Environmental Protection Agency, 1999. Report EPA 841-B-99-002.

BRUA, R., CULP, J. and BENOY, G. Comparison of benthic macroinvertebrate communities by two methods: Kick- and U-net sampling. Hydrobiologia, 2011, 658(1), 293-302. http://dx.doi.org/10.1007/ s10750-010-0499-x.

BUSS, D.F. and BORGES, E.L. Application of rapid bioassessment protocols (RBP) for benthic macroinvertebrates in Brazil: comparison between sampling techniques and mesh sizes. Neotropical Entomology, 2008, 37(3), 288-295. http://dx.doi. org/10.1590/S1519-566X2008000300007.

PMid:18641899

BUSS, D.F., CARLISLE, D.M., CHON, T.S., CULP, J., HARDING, J.S., KEIZER-VLEK, H.E., ROBINSON, W.A., STRACHAN, S., THIRION, C. and HUGHES, R.M. Stream biomonitoring using macroinvertebrates around the globe: a comparison of large-scale programs. Environmental Monitoring and Assessment, 2015, 187(1), 4132. http://dx.doi. org/10.1007/s10661-014-4132-8. PMid:25487459
ClAPCOTT, J., COLliER, K., DEATH, R., GOODWIN, E., HARDING, J., KELLY, D., LEATHWICK, J. and YOUNG, R. Quantifying relationships between landuse gradients and structural and functional indicators of stream ecological integrity. Freshwater Biology, 2012, 57(1), 74-90. http://dx.doi.org/10.1111/j.13652427.2011.02696.x.

DALLAS, H., KENNEDY, M., TAYLOR, J., LOWE, S. and MURPHY, K. WP4: Review of existing biomonitoring methodologies and appropriateness for adaptation to river quality assessment protocols for use in southern tropical Africa. South Africa: University of Cape Town, 2010.36 p. Safrass: Southern African River Assessment Scheme.

DALLAS, H.F. Wetland monitoring using aquatic macroinvertebrates. South Africa: University of Cape Town, 2009, 72 p. Prepared for the Biokavango Project, Harry Oppenheimer Okavango Research Centre, University of Botswana. Technical Report. Report 5/2009.

DICKENS, C.W. and GRAHAM, P.M., and the DICKENS. The South African Scoring System (SASS) Version 5: rapid bioassessment method for rivers. African Journal of Aquatic Science, 2002, 27(1), 1-10. http://dx.doi.org/10.2989/16085914. 2002.9626569.

DURANCE, I. and ORMEROD, S. Trends in water quality and discharge confound long-term warming effects on river macroinvertebrates. Freshwater Biology, 2009, 54(2), 388-405. http://dx.doi. org/10.1111/j.1365-2427.2008.02112.x.

FRIBERG, N., SKRIVER, S., LARSEN, S., PEDERSEN, M. and BUFFAGNI, A. Stream macroinvertebrate occurrence along gradients in organic pollution and eutrophication. Freshwater Biology, 2010, 55(7), 1405-1419. http://dx.doi. org/10.1111/j.1365-2427.2008.02164.x.

HARTMANN, A., MOOG, O. and STUBAUER, I. "HKH screening": a field bio-assessment to evaluate the ecological status of streams in the Hindu KushHimalayan region. Hydrobiologia, 2010, 651(1), 2537. http://dx.doi.org/10.1007/s10750-010-0288-6.

HILL, M. TWINSPAN - a Fortran program for arranging multivariate data in an ordered two way table by classification of the individual and the attributes. Ithaca: Cornell University, 1979. 120 p.

JUNQUEIRA, M.V. and CAMPOS, S.C.M. Adaptation of the "BMWP" method for water quality evaluation to Rio das Velhas watershed (Minas Gerais, Brazil). Acta Limnologica Brasiliensia, 1998, 10, 125-135.

JUNQUEIRA, M.V., AMARANTE, M.C., DIAS, C.F.S. and FRANÇA, E.S., Biomonitoramento da qualidade das águas da Bacia do Alto Rio das Velhas 
(MG/Brasil) através de macroinvertebrados. Acta Limnologica Brasiliensia, 2000, 12, 73-87.

LOWE, S. Photographic guide to the aquatic invertebrates of Zambia. Glasgow: University of Glasgow, 2012, 16 p. SAFRASS Deliverable Report to African, Caribbean and Pacific Group of States ACP Group Science and Technology Program, Contract No. AFS/2009/219013.

LOWE, S., DALLAS, H., KENNEDY, M., TAYLOR, J., GIBBINS, C., LANG, P., SICHINGABULA, H., SAILI, K., NTOBOLO, C., KABANGU, K., DAY, J., WILLEMS, F., BRIGGS, J. and MURPHY, K. The SAFRASS biomonitoring scheme: general aspects, macrophytes (ZMRT) and benthic macroinvertebrates (ZISS) protocols. Glasgow: University of Glasgow, 2012a, 15 p. SAFRASS Deliverable Report to African, Caribbean and Pacific Group of States ACP Group Science and Technology Program, Contract No. AFS/2009/219013.

LOWE, S., DALLAS, H., KENNEDY, M., TAYLOR, J., GIBBINS, C., LANG, P., SICHINGABULA, H., SAILI, K., NTOBOLO, C., KABANGU, K., DAY, J., WILLEMS, F., BRIGGS, J. and MURPHY, K. SAFRASS methodology manual. Glasgow: University of Glasgow, 2012b, 36 p. SAFRASS Deliverable Report to African, Caribbean and Pacific Group of States ACP Group Science and Technology Program, Contract No. AFS/2009/219013.

LOWE, S., DALLAS, H., KENNEDY, M., TAYLOR, J., GIBBINS, C., LANG, P., SICHINGABULA, H., SAILI, K., NTOBOLO, C., KABANGU, K., DAY, J., WILLEMS, F., BRIGGS, J. and MURPHY, K. Assessment of performance of the pilot river biomonitoring scheme. Glasgow: University of Glasgow, 2012c, 27 p. SAFRASS Deliverable Report to African, Caribbean and Pacific Group of States ACP Group Science and Technology Program, Contract No. AFS/2009/219013.

MELO, S., STENERT, C., DALZOCHIO, M. S. and MALTCHIK, L. Development of a multimetric index based on aquatic macroinvertebrate communities to assess water quality of rice fields in southern Brazil. Hydrobiologia, 2015, 742(1), 1-14. http://dx.doi. org/10.1007/s10750-014-1957-7.

MONTEIRO, T.R., OLIVEIRA, L.G. and GODOY, B.S. Biomonitoramento da qualidade da água utilizando macroinvertebrados bentônicos: adaptaçâo do índice biótico BMWP à Bacia do Rio Meia Ponte - GO. Oecologia Brasiliensis, 2008, 12, 553-563.

MURPHY, K., KENNEDY, M., MCCARTHY, V., O'HARE, M., IRVINE, K. and ADAMS, C. $A$ review of ecology based classification systems for standing freshwaters. Edinburgh: SNIFFER, 2002, p. 134.
Environment Agency R\&D Technical Report: E1091/TR.

NEAL, C. Alkalinity measurements within natural waters: towards a standardised approach. The Science of the Total Environment, 2001, 265(1-3), 99-113. http://dx.doi.org/10.1016/S0048-9697(00)00652-5. PMid:11227286

OGBEIBU, A.E. and ORIBHABOR, B.J. Ecological impact of river impoundment using benthic macroinvertebrates as indicators. Water Research, 2002, 36(10), 2427-2436. http://dx.doi.org/10.1016/ S0043-1354(01)00489-4. PMid:12153008

OLLIS, D.J., DALLAS, H.F., ESLER, K.J. and BOUCHER, C. Bioassessment of the ecological integrity of river ecosystems using aquatic macroinvertebrates: an overview with a focus on South Africa. African Journal of Aquatic Science, 2006, 31(2), 205-227. http://dx.doi. org/10.2989/16085910609503892.

PALMER, C., MAART, B., PALMER, A. and O'KEEFFE, J. An assessment of macroinvertebrate functional feeding groups as water quality indicators in the Buffalo River, eastern Cape Province, South Africa. Hydrobiologia, 1996, 318(3), 153-164. http:// dx.doi.org/10.1007/BF00016677.

PALMER, R.W. and TAYLOR, E.D., and the PALMER The Namibian Scoring System (NASS) version 2 rapid bio-assessment method for rivers. African Journal of Aquatic Science, 2004, 29(2), 229-234. http://dx.doi.org/10.2989/16085910409503814.

ROQUE, F.O., LECCI, L.S., SIQUEIRA, T. and FROEHLICH, C.G. Using environmental and spatial filters to explain stonefly occurrences in Southeastern Brazilian streams: Implications for biomonitoring. Acta Limnologica Brasiliensia, 2008, 20, 117-130.

SILVEIRA, M.P., BAPTISTA, D.F., BUSS, D.F., NESSIMIAN, J.L. and EGLER, M. Application of biological measures for stream integrity assessment in south-east Brazil. Environmental Monitoring and Assessment, 2005., 101(1-3), 117-128. PMid: 15736880.

SMITH, M.J., KAY, W.R., EDWARD, D.H.D., PAPAS, P.J., RICHARDSON, K.S.J., SIMPSON, J.C., PINDER, A.M., CALE, D.J., HORWITZ, P.H.J., DAVIS, J.A., YUNG, F.H., NORRIS, R.H. and HALSE, S.A. AusRivAS: using macroinvertebrates to assess ecological condition of rivers in Western Australia. Freshwater Biology, 1999, 41(2), 269-282. http://dx.doi.org/10.1046/j.13652427.1999.00430.x.

SWEDISH ENVIRONMENTAL PROTECTION AGENCY. Environmental quality criteria: lakes and 
water courses. Stockholm: Swedish Environmental Protection Agency, 2000, p. 102. Report 5050.

TER BRAAK, C. and SMILAŬER, P. CANOCO reference manual and users guide to Canoco for Windows: software for canonical community ordination. Version 4. Ithaca: Micro-computer Power, 1998, p. 351.

TURLEY, M., BiLOTTA, G., EXTENCE, C. and BRAZIER, R. Evaluation of a fine sediment biomonitoring tool across a wide range of temperate rivers and streams. Freshwater Biology, 2014, 59(11), 2268-2277. http://dx.doi.org/10.1111/fwb.12429.

WORLD WIDE FUND FOR NATURE - WWF, THE NATURE CONSERVANCY - TNC. Freshwater ecoregions of the world [on line]. Washington, 2013 [viewed 10 Aug. 2013]. Available from: http://www. feow.org

WRIGHT, J., FURSE, M. and MOSS, D. River classification using invertebrates: RIVPACS applications. Aquatic Conservation: Marine and Freshwater Ecosystems, 1998, 8(4), 617-631. http://dx.doi.org/10.1002/ (SICI) 1099-0755(199807/08)8:4<617::AIDAQC255>3.0.CO;2-\#.

XU, M., WANG, Z., DUAN, X. and PAN, B. Effects of pollution on macroinvertebrates and water quality bio-assessment. Hydrobiologia, 2014, 729(1), 247259. http://dx.doi.org/10.1007/s10750-013-1504-y.

Received: 18 November 2013 Accepted: 08 April 2015 